\title{
Overcoming dormancy of Senna multijuga seeds with an ultrasonic probe the comparison with ultrasound and sulfuric acid baths
}

\author{
Renata Samara da Silva Venâncio ${ }^{1^{*}}$ (D) Antonio Cesar Germano Martins $^{1}$
}

'Departamento de Engenharia, Universidade Estadual Paulista (UNESP), Instituto de Ciência e Tecnologia, 18087-180, Sorocaba, SP, Brasil. E-mail: s_renata@hotmail.com. "Corresponding author.

ABSTRACT: Understanding germination is extremely important for the production of seedlings that are used in revegetation of degraded areas. Some species enter dormancy as a survival strategy to overcome adverse environmental conditions. Their seeds germinate only when this process is interrupted, which can occur naturally when the conditions become more favorable for the survival of the species or by induction. Studies showed that ultrasound can increase the germination rate of seeds. The objective of this research was to evaluate the effect of an ultrasound probe and compare it with other methodologies implemented for seed germination of Senna multijuga (Rich.) H. S. Irwin \& Barneby, a species used in revegetation of degraded areas. The experiment evaluated the effect of the ultrasonic probe at different powers on seeds that were placed to germinate in a gerbox on paper moistened with distilled water. Ninety-five percent of seeds treated with ultrasound and only $14 \%$ of non-treated seeds (control) germinated. There was no significant difference in the germination among the treatments with different powers. The speed of germination index (SGI) reached 4.7 in seeds that underwent the treatment, and 0.6 in the control group. From the results it is possible to conclude that the ultrasound probe is an efficient treatment to accelerate seed germination in this species; and consequently, contributed to production of a greater number of seedlings to be used in revegetation of degraded areas in a short period of time. Key words: Senna multijuga (Rich.) H. S. Irwin \& Barneby, germination, seeds, ultrasound, revegetation.

Superação da dormência de sementes de Senna multijuga com sonda ultrassônica e a comparação com banho de ultrassom e ácido sulfúrico

RESUMO: Entender a germinação é extremamente importante para produção de mudas utilizadas na revegetação de áreas degradadas. Algumas espécies são consideradas dormentes por apresentarem uma estratégia de sobrevivência para superar condições ambientais adversas. Essas sementes germinam apenas quando esse processo é interrompido, o que pode ocorrer naturalmente quando as condições se tornam mais favoráveis para a sobrevivência da espécie ou de forma induzida. Estudos demonstram que o ultrassom pode aumentar a taxa de germinação das sementes. Esse trabalho teve como objetivo avaliar o efeito da sonda ultrassom e compará-la com outras metodologias utilizadas para a germinação de sementes de Senna multijuga (Rich.) H. S. Irwin \& Barneby, espécie utilizada na revegetação de áreas degradadas. O experimento avaliou o efeito da sonda de ultrassom em diferentes potências sobre as sementes, que foram colocadas para germinar em gerbox sobre papel umedecido com água destilada. Das sementes que sofreram o tratamento com a sonda de ultrassom 95\% germinaram, já das que não sofreram nenhum tratamento apenas $14 \%$ delas germinaram. Não houve diferença significativa entre as diferentes potências avaliadas. $O$ indice de velocidade de germinação (IVG) chegou a 4,7 em sementes que sofreram o tratamento e 0,6 no grupo controle. A partir dos resultados é possivel concluir que a sonda de ultrassom é um tratamento eficiente para acelerar a germinação de sementes desta espécie e, consequentemente, contribuir para produção de um maior número de mudas em curto período para serem utilizadas na revegetação de áreas degradadas. Palavras-chave: Senna multijuga (Rich.) H. S. Irwin \& Barneby, germinação, sementes, ultrassom, revegetação.

\section{INTRODUCTION}

Senna multijuga (Rich.) H. S. Irwin \& Barneby (Pau-cigarra) is a tree species belonging to the Fabaceae family and distributed in the Atlantic Forest. It is of great environmental importance, because as a pioneer species it is recommended in the revegetation of degraded areas (LORENZI, 2008). Native tree species are fundamental in the recovery of degraded areas (BARBOSA et al., 2003), because they reduce environmental impact and conserve biodiversity (CARNEIRO et al., 1998) and keep the balance of physical, chemical and biological processes in the soil (CASSIOLATO et al., 2010).

Understanding seed germination, developing methods for fast production of a large number of germinated seeds, and generating seedlings with high vigor, are extremely important for revegetation (VENÂNCIO et al., 2013).

Germination is nothing more than a sequence of physiological events in the embryo that begins with soaking of seeds and ends by the 
protrusion of the radicle through the seed coat (FERREIRA et al., 2004).

External factors are necessary for germination to commence, such as the presence of light, water and oxygen. However, even when those conditions are met, viable seeds of many species will not germinate when they are in the state of dormancy.

Dormancy can be defined as an evolutionary mechanism that aims to protect and insure species perpetuation. It is a survival strategy adopted to overcome adverse environmental conditions and ensure seed germination only when the conditions adequate for the species survival (MORI et al., 2012).

Seeds of $S$. multijuga enter physical dormancy, rendering their use for revegetation challenging. This dormancy is caused by a waterimpermeable layer (a layer in the integument of the seed), preventing the imbibition and; consequently, the beginning of the germination (BASKIN et al., 2000).

There are several techniques developed to break seed dormancy and accelerate germination. Seed immersion in water that was heated to $100{ }^{\circ} \mathrm{C}$ (MORI et al., 2012) and scarification with sulfuric acid (PINTO, 2013) are the most used treatments to break dormancy of $S$. multijuga seeds.

Seed dormancy prevents germination from occurring simultaneously in all seeds; and therefore, there is a need to create low-cost, fast, and highly efficient techniques for breaking seed dormancy. One such methodology capable of breaking seed dormancy is low-frequency ultrasound.

Application of low-frequency ultrasound in liquid media facilitates the uptake of water by the seeds; consequently, increasing the rate of germination and growth (YALDAGARD et al., 2008; VENÂNCIO et al., 2015). Ultrasonic vibrations in liquid media generate cavitation bubbles, which are responsible for the release of large amounts of energy (FU, 2009; WHEATLEY, 1990), contributing to the breakdown of seed dormancy. However, the applied dosage and the length of exposure to ultrasonic waves have different degrees of influence on the germination process (PASSOS et al., 2013; VENÂNCIO et al., 2016).

Usually, two types of equipment capable of generating ultrasound waves are used in laboratory: a bath and a probe. The bath is usually used to clean the materials; its energy is transmitted through a liquid from a piezoelectric transducer located on the bottom of the tank, which ensures that energy is more dispersed. The probe is generally used to break cell membranes, thus freeing the intracellular material to be investigated. The probe is attached to the end of the amplifier of the transducer and has a direct contact with the sample. Therefore, it is considered more efficient than the bath, as bath energy is more dispersed (BARBOZA et al., 1992; VENÂNCIO et al., 2015).

The objective of this research was to evaluate the effects of ultrasonic probe on seed germination of $S$. multijuga and to compare them with the effects of ultrasonic bath and chemical scarification with sulfuric acid.

\section{MATERIALS AND METHODS}

The study was carried out from October 2016 to April 2017, at the São Paulo State University (UNESP) in Sorocaba, SP. Seed lots of S. multijuga were purchased from the supplier Toca do Verde, located in the state of Paraná/Brazil. After receiving the seeds, they were conditioned in a refrigerator at $10{ }^{\circ} \mathrm{C}$ until their use.

The experimental design was completely randomized, with treatments distributed in a $3 \times 2$ factorial arrangement (three powers of the ultrasound probe and two treatment times in the ultrasound bath) with five replicates, each containing 35 seeds.

For germination, the seeds were distributed in gerbox, on top of two sheets of filter paper that were moistened with distilled water in an amount equivalent to 2.5 times the dry weight of the paper (BRASIL, 2009). Fungicide was applied and the boxes were kept in a germination chamber at $30{ }^{\circ} \mathrm{C}$ for 35 days under constant white light.

Seeds were divided into there groups: the control group, the treated with the ultrasound bath and the group treated with the ultrasound probe. The control group was composed of two subgroups: $\mathrm{GC} 1$, composed of seeds that did not undergo any type of treatment, and GC2, composed of seeds that were immersed in concentrated sulfuric acid for 5 minutes and then washed with running water (PINTO, 2013).

The second group was treated with an ultrasound bath (model STD; BioWash) with a tank capacity of $2.5 \mathrm{~L}$, power of $160 \mathrm{~W}$, and a constant frequency of $42 \mathrm{kHz}$. Treatment was performed at constant room temperature for different immersion times ( 2 and 4 minutes) in $1000 \mathrm{~mL}$ of purified water. To avoid energy dispersion, seeds were concentrated in the central region of the bath with the aid of an acrylic container, where the greatest amount of cavitation energy of the equipment was released.

The third group consisted of seeds that underwent treatment with ultrasound probe (model 
QR500; Eco-Sonics) with macropoint, power of 500 $\mathrm{W}$, and constant frequency of $20 \mathrm{kHz}$. The probe was attached to the end of the piezoelectric transducer amplifier, allowing direct contact with the sample and lower energy dispersion. Treatment was conducted at different powers $(250,350$, and $450 \mathrm{~W})$ with immersion in $70 \mathrm{~mL}$ of distilled water for 5 minutes.

Seeds were considered germinated when the radicle emergence occurred and the seedlings were regarded normal if they could present potential to continue their development and give rise to normal plants, that is, they did not develop any malformations (BRASIL, 2009).

Number of germinated seeds, percentage of normal seedlings and speed of germination index (SGI) were analyzed using the following equation:

$$
\mathrm{SGI}=G_{1} / N_{1}+G_{2} / N_{2}+\ldots+G_{n} / N_{n}
$$

Where:

$G_{1}, G_{2}, G_{n}$ are respectively, the number of germinated seeds computed at the first, second, and last count, and $\mathrm{N}_{1}, \mathrm{~N}_{2}, \mathrm{~N}_{\mathrm{n}}$ are the number of sowing days at the first, second, and last count, respectively (LIN, 1988).

The obtained data were evaluated with the analysis of variance (Anova), and the means were compared with the Tukey test at 5\% probability. The analyses were performed with the PAST v. $2.17 \mathrm{c}$ program. (HAMMER et al., 2001).

\section{RESULTS AND DISCUSSION}

The was no significant difference in the seed germination rate between the two treatments ( 2 and 4 minutes) in the ultrasonic bath: $65 \%$ of the seeds that were kept for 2 minutes in the bath and $68 \%$ of the seeds kept for 4 minutes germinated after the treatment. Only $20 \%$ of the seeds from the control group germinated, highlighting the need for a treatment to break seed dormancy in this species (Figure 1).

VENÂNCIO et al. (2016), who conducted a similar study with the same species using ultrasonic bath with different times (1, 2, 4, 8, and 10 minutes) to break the seed dormancy, reported the highest percentage of germination in seeds that were kept 2 and 4 minutes in the ultrasound bath. They also observed that seed germination was affected by the duration of the treatment in the ultrasound bath: shorter treatment failed to break the dormancy and a longer treatment resulted in death of the embryo.

PASSOS et al. (2013) exposed the seeds of Gliricidia sepium (Jacq.) Steud. to different times (2, 4, 8 and 16 minutes) in the ultrasound bath and reported the highest germination percentage and SGI in seeds that were treated for 2 minutes. Other studies showed that the ultrasonic bath is also efficient in the germination of grass seeds where it promotes the absorption of water by the seeds,

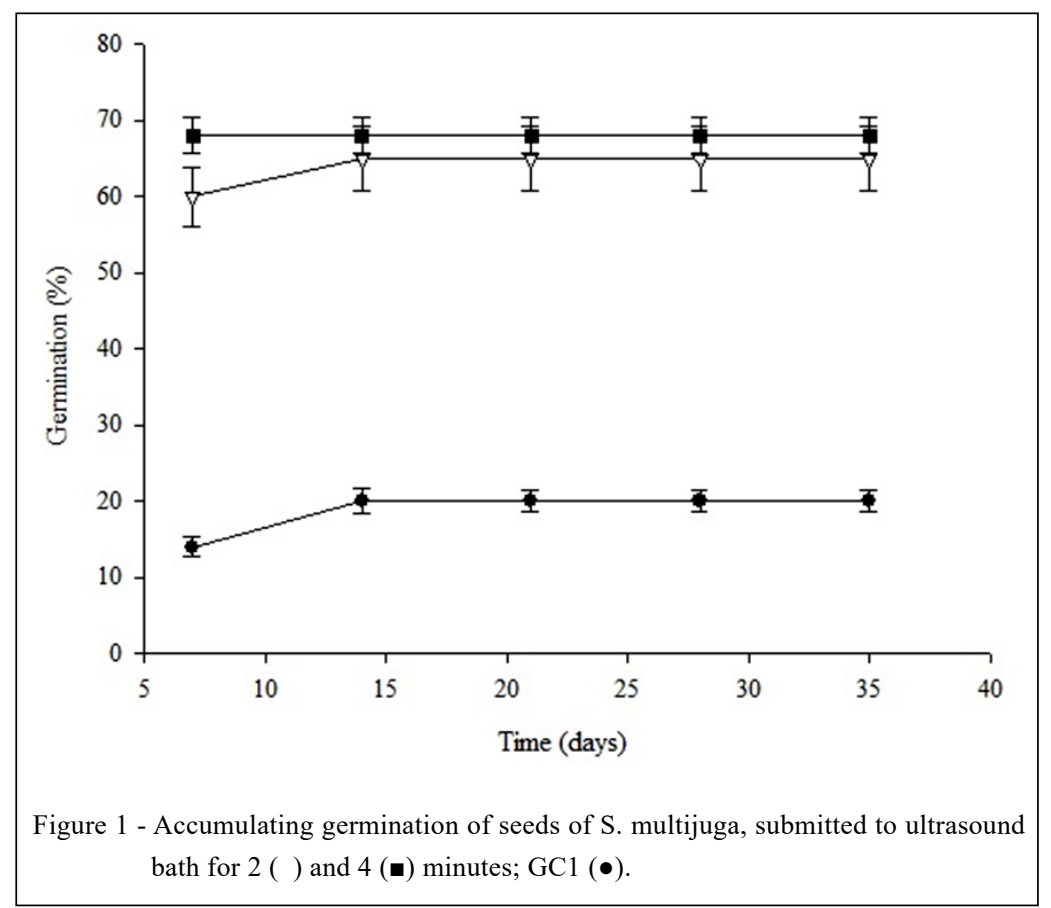

Ciência Rural, v.49, n.9, 2019. 
reducing the germination period (CHEN et al., 2012; KRATOVALIEVA et al., 2012).

The highest percentage of germination, $95 \%$ was obtained with the ultrasound probe. The seed germination rate after exposure to $250 \mathrm{~W}$, $350 \mathrm{~W}$, and $450 \mathrm{~W}$ of ultrasound probe was $94 \%$, $100 \%$ and $97 \%$, respectively (Figure 2). There was no significant difference in the germination rate between the different powers, but the differences was significant between the seeds treated with the ultrasound probe and the control seeds that did not undergo any treatment.

PINTO et al. (2013) examined the effect of different treatments on seed dormancy in $S$. multijuga and obtained the highest germination rate of $92 \%$ in seeds that were immersed in concentrated sulfuric acid for 5 minutes. In the present study, $97 \%$ of the seeds germinated after being treated with concentrated sulfuric acid for 5 minutes.

The results in this study showed that the ultrasonic probe with of $350 \mathrm{~W}$ and the treatment with sulfuric acid resulted in the highest germination percentage for $S$. multijuga, both methods produced results that were not significantly different (Figure 3 ). However, because of the damage that sulfuric acid can cause to the environment and human health, the ultrasound probe is a preferred clean technology as it does not generate toxic waste in the environment and does not endanger human health.

Accelerating seed germination is extremely important for species used in the revegetation of degraded areas, because the faster the revegetation, the faster the recovery of the ecosystem.

Seeds of $S$. multijuga that underwent ultrasonic probe treatment showed a higher germination speed, reaching an SGI of 4.7, a very similar result was observed in seeds immersed in concentrated sulfuric acid. Statistical analysis showed no significant difference in the germination speed between the different powers tested, but there was a significant difference in SGI between the seeds treated with ultrasonic probe and those that did not undergo any treatment (SGI of 0.6) (Figure 4). Similarly, there was no significant difference in SGI between the different time with the ultrasound bath, but the difference was significant when compared with the SGI results of the seeds treatment with the ultrasound probe and seeds that were not subjected to any treatment.

Evaluating the formation of normal seedlings from those that had been treated with the bath and the ultrasound probe, with concentrated

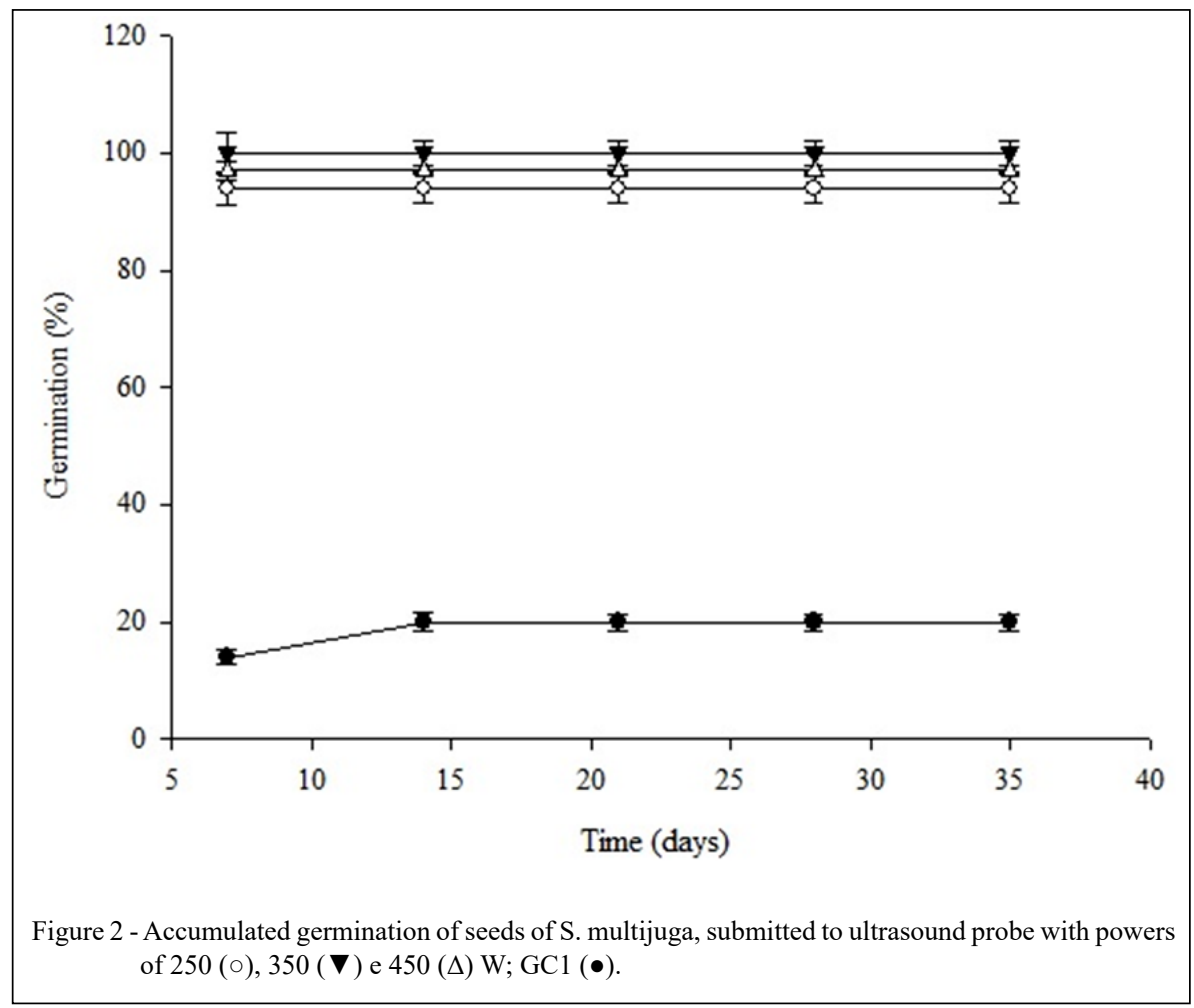

Ciência Rural, v.49, n.9, 2019. 


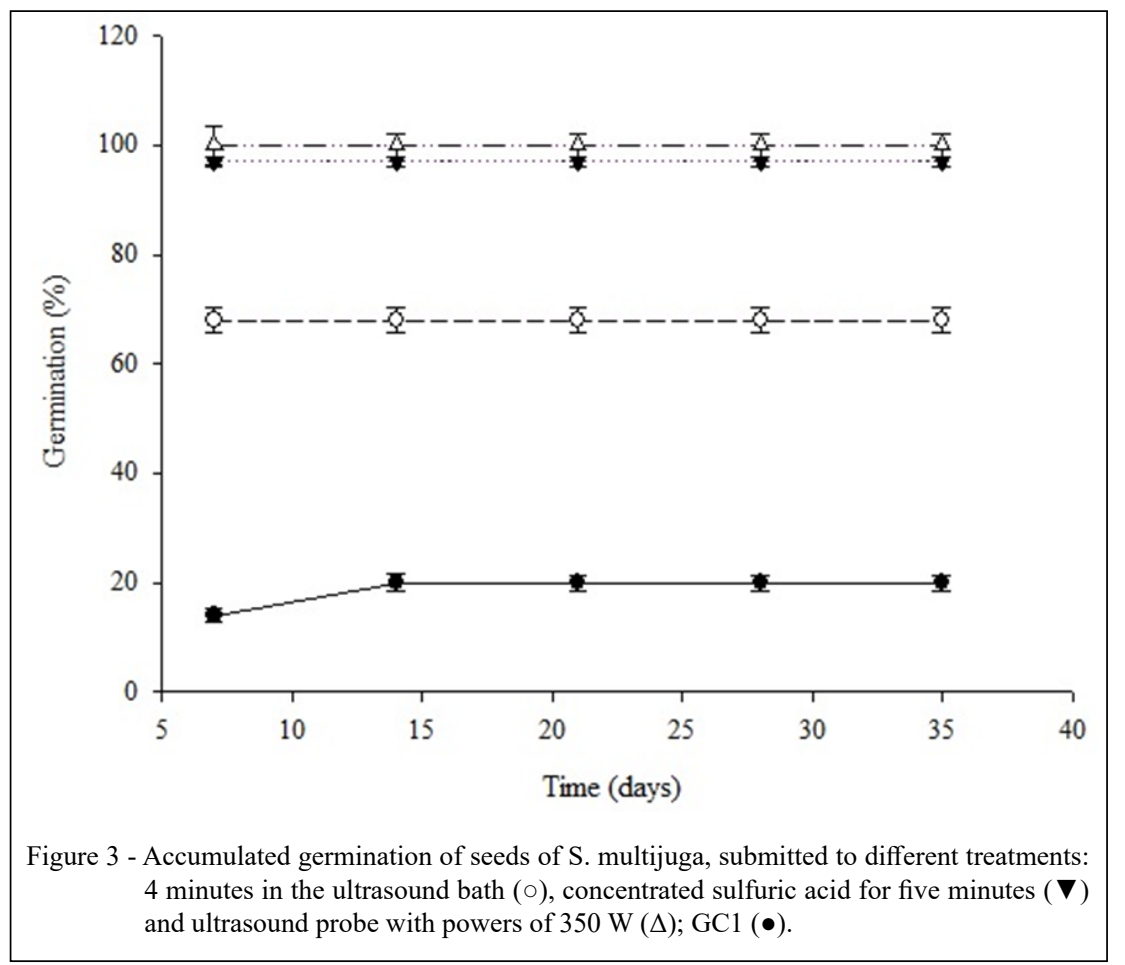

sulfuric acid and those that did not undergone any treatment, the results followed the same pattern. The highest percentage of normal seedlings was obtained from seeds that underwent treatment with ultrasound probe and those that were treated with concentrated sulfuric acid. These data suggested that the treatment with ultrasound probe for 5 minutes, which resulted in the formation of larger percentage of normal

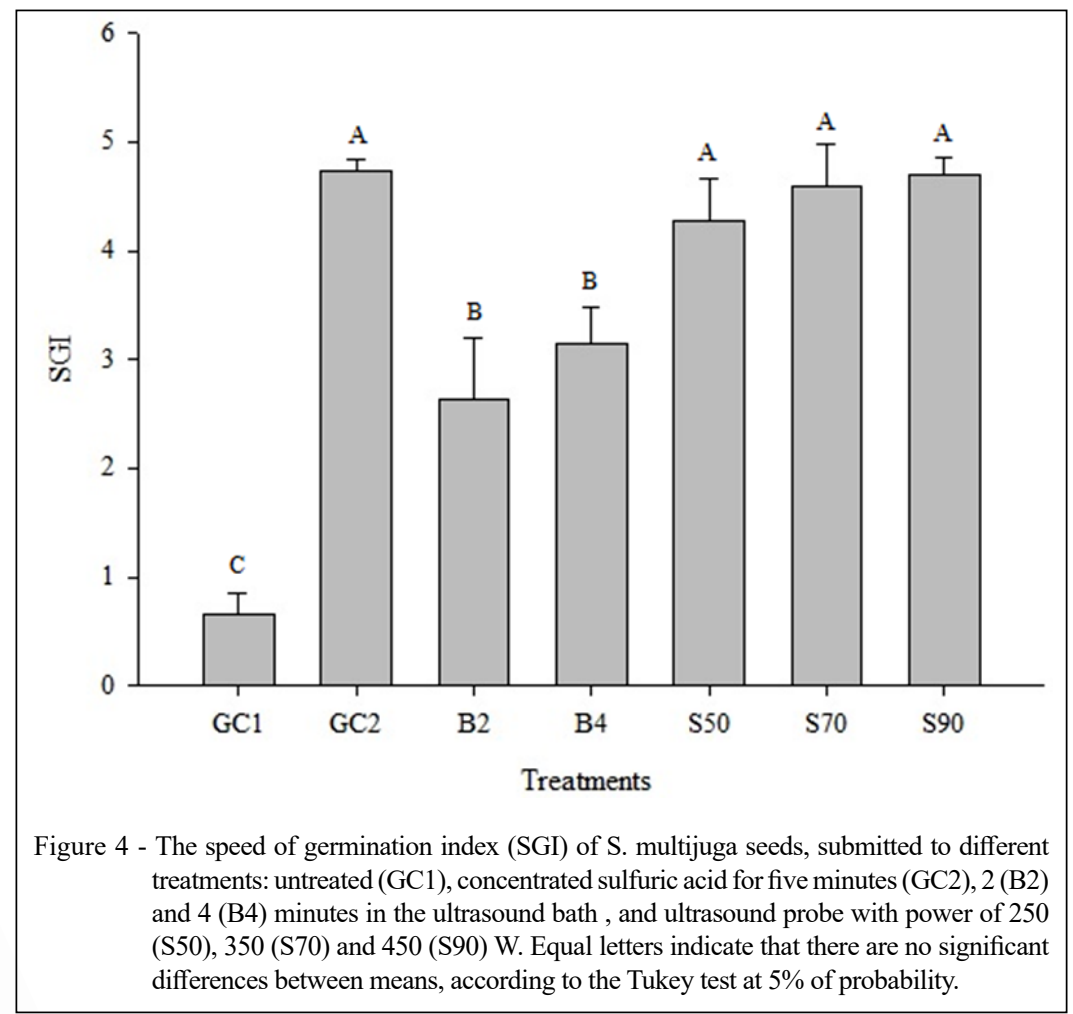

Ciência Rural, v.49, n.9, 2019. 
seedlings, favor the elimination of the causes responsible for dormancy considering the formation of larger percentages of normal seedlings. Thus, 5 minutes long treatment of seeds with ultrasound probe is probably the best suited method for the seedling production of $S$. multijuga.

In general, these results demonstrated that ultrasonic radiation accelerates the seed germination process of $S$. multijuga, contributing to the fast production of seedlings with high vigor that can in a short time be used in revegetation of degraded areas.

Although, the application of sulfuric acid also presented optimal results, it should be emphasized that its application can cause serious damage to the health of the researcher and pose a risks to the environment.

Besides being very efficient in breaking seed dormancy, the ultrasound probe treatment is low cost, it does not generate residues that can be released into the environment, and it is easy to handle, and thus very promising for the production of seedlings of species that are used for revegetation of degraded areas.

\section{CONCLUSION}

Results of the tests conducted in this study suggested ultrasound probe is a well suited treatment for breaking seed dormancy in S. multijuga and no significant difference between different ultrasound probe powers was reported in the experiments.

Ultrasound probe increaseds the germination rate when compared with ultrasound bath and produces similar results to those obtained with the sulfuric acid bath, but with the advantage of being more environmentally friendly.

\section{DECLARATION OF CONFLICT OF} INTERESTS

The authors declare no conflict of interest. The founding sponsors had no role in the design of the study; in the collection, analyses, or interpretation of data; in the writing of the manuscript, and in the decision to publish the results.

\section{REFERENCES}

BARBOSA, L. M. et al. Forest recovery with native species in the state of São Paulo: research indicates necessary changes. Florestar Estatístico, São Paulo, v.14, p.28-34, jan. 2003. Available from: <https://www.researchgate.net/ publication/300006497_Recuperacao_florestal_com_especies_ nativas_no_Estado_de_Sao_Paulo_Pesquisas_apontam mudancas_necessarias>. Accessed: Dec. 05, 2017.

BARBOZA, J. C. S.; SERRA, A. A. Ultra-som: Influência do ultrasom na química. Química Nova, Lorena, v.15, n.4, p.302-316, 1992.
Available from: <http:/quimicanova.sbq.org.br/imagebank/pdf/ Vol15No4_302_v15_n4_\%286\%29.pdf>. Accessed: Nov. 22, 2017.

BASKIN, J. M.; BASKIN, C. C. Evolutionary considerations of claims for physical dormancy-break by microbial action and abrasion by soil particles. Seed Science Research, New York, v.10, n. 4, p.409-413, Dec. 2000. Available from: <https:// www.researchgate.net/publication/231948330_Evolutionary_ considerations_of_claims_for_physical_dormancy-break_by_ microbial_action_and_abrasion_by_soil_particles>. Accessed: Oct. 10,2017 . do $\bar{i}: 10.1017 / \mathrm{S} 0960258500000453$.

BRASIL. Ministério da Agricultura, Pecuária e Abastecimento. Regras para análise de sementes. Ministério da Agricultura, Pecuária e Abastecimento. Secretaria de Defesa Agropecuária. Brasília: MAPA/ACS, 2009. 395p.

CARNEIRO, M. A. C. et al. Micorriza arbuscular em espécies arbóreas e arbustivas nativas de ocorrência no sudeste do Brasil. Cerne, Lavras, v.4, n.1, p.129-145, 1998. Available from: <http:// www.bibliotecaflorestal.ufv.br:80/handle/123456789/18292>. Accessed: Nov. 2, 2017.

CASSIOLATO, A. M. R.; et al., Growth leaf, acid phosphatase activity and mycorrhization of tree species on degraded cerrado soil. Bragantina, Campinas, v.69, n.2, p.445-451, 2010. Available from: $\quad<$ http://dx.doi.org/10.1590/S0006-87052010000200024>. Accessed: Sep. 10,2017. doi: 10.1590/S0006-87052010000200024.

CHEN, G. et al. Modelling analysis for enhancing seed vigour of switchgrass (Panicum virgatum L.) using an ultrasonic technique. Biomass and Bioenergy, v.47, p.426-435, Dec. 2012. Available from: <https://doi.org/10.1016/j.biombioe.2012.09.015>. Accessed: Nov. 10, 2017. doi: 10.1016/j.biombioe.2012.09.015.

FERREIRA, R. A. Vigor e viabilidade de sementes de Senna multijuga (Rich.) Irwin et Barn. e Senna macranthera (Collad.) Irwin et Barn., num banco de sementes em solo de viveiro. Revista Brasileira de Sementes, Pelotas, v.26, n.1, p.2431, 2004. Available from: <http://dx.doi.org/10.1590/S010131222004000100004>. Accessed: Oct. 03, 2017. doi: 10.1590/ S0101-31222004000100004

FU, T. T.; et al.,. Bubble formation and breakup mechanism in a microfluidic flow-focusing device. Chemical Engineering Science, v.64, n.10, p.2392-2400, 2009. Available from: <https:// doi.org/10.1016/j.ces.2009.02.022>. Accessed: Oct. 03, 2017. doi: 10.1016/j.ces.2009.02.022.

HAMMER, O.; et al.,. Past: Paleontological statistics software package for education and data analysis. Palaeontologia Electronica, v.4, n.1, p.1-9, Jun. 2001. Available from: <http://palaeo-electronica. org/2001_1/past/issue1_01.htm>. Accessed: Oct. 21, 2017.

KRATOVALIEVA, S. et al. Ultrasound influence on coleoptile length at Poaceae seedlings as valuable criteria in prebreeding and breeding processes. Genetika, v.44, n.3, p.561-570, Jan. 2012. Available from: <https://www.researchgate.net/ publication/270469959_Ultrasound_influence_on_coleoptile_ length_at_Poaceae_seedlings_as_valuable_criteria_in prebreeding_and_breeding_processes $>$. Accessed: Nov. $22, \overline{2} 017$. doi: $10.2298 / \mathrm{GEN} S R 1203561 \mathrm{~K}$.

LORENZI, H. Árvores Brasileiras: manual de identificação e cultivo de plantas arbóreas nativas do Brasil. 5 ed. São Paulo: Instituto Plantarum, 2008. 384p. 
MORI, E. S.; PIÑA-RODRIGUES, F. C. M.; FREITAS, N. P. Sementes florestais: Guia para germinação de 100 espécies nativas. 1. ed. São Paulo: Instituto Refloresta, 2012. 159p.

PASSOS, A. M. A. et al. Efeito de banho de ultrassom de baixa frequência sobre a germinação e vigor de sementes de gliricídia (Gliricidia sepium). In: CONGRESSO BRASILEIRO DE SEMENTES, 18, 2013. Paraná. Anais do Congresso Brasileiro de Sementes. Paraná: Congresso Brasileiro de Sementes, 2013.

PINTO, T. T. Morfoanatomia e fisiologia de sementes com dormência física de Colubrina glandulosa Perkins (Rhamnaceae) e Senna multijuga (Rich.) H. S. Irwin \& Barneby (Caesalpinioideae- Fabaceae). 2013. 71f. Dissertação (Mestrado em Biologia de Fungos, Algas e Plantas) - Universidade Federal de Santa Catarina. Florianópolis, 2013.

VENÂNCIO, R. S. S.; MIURA, R. Y. H. Analysis of germination rates of four indigenous species: Rapanea ferruginea (Ruiz \& Pav.) Mez., Euterpe edulis Mart., Peschiera fuchsiaefolia Miers, and Enterolobium contortisiliquum (Vell.) Morong. Scientia Vitae, São Roque, v.1, n.1, p.3-11, Dec. 2013. Available from: $<$ http://www. revistaifspsr.com/sv_v1_n2_1.pdf>. Accessed: Nov. 25, 2017.

VENÂNCIO, R. S. S.;et al.,. Environmental technology: applications of ultrasound. International Journal of
Engineering and Applied Sciences, Jaipur, v.7, n.2, p.1-5, Jul. 2015. Available from: <http://eaas-journal.org/survey/ userfiles/ files/v7i201\%20Environmental\%20Engineering(1).pdf $>$. Accessed: Nov. 25, 2017.

VENÂNCIO, R. S. S.; et al.,Técnicas alternativas de quebra de dormência: uso do ultrassom de baixa frequência em sementes de pau-cigarra (Senna multijuga (Rich.) H. S. Irwin \& Barneby). Perspectivas em Ciências Tecnológicas, Pirassununga, v.5, n.5, p.28-42, May. 2016. Available from: <http://fatece.edu. br/arquivos/arquivos\%20revistas/perspectiva/volume 5/2.pdf $>$. Accessed: Nov. 15, 2017.

WHEATLEY, M. A.; et al. Contrast agents for diagnostic ultrasound: development and evaluation of polymer-coated microbubbles. Biomaterials, v.11, n.9, p.713-717, 1990. Available from: <https:// doi.org/10.1016/0142-9612(90)90033-M>. Accessed: Dec. 02, 2017. doi: 10.1016/0142-9612(90)90033-M.

YALDAGARD, M.;et al.,. Application of ultrasonic waves as a priming technique for accelerating and enhancing the germination of barley seed: optimization of method by the taguchi approach. Journal of the Institute of Brewing, Medford, v.114, n.1, p.1421, Jan. 2008. Available from: <http://onlinelibrary.wiley.com/ doi/10.1002/j.2050-0416.2008.tb00300.x/epdf $>$. Accessed: Dec. 05, 2017. doi: 10.1002/j.2050-0416.2008.tb00300.x. 